\title{
Esophageal Infection
}

National Cancer Institute

\section{Source}

National Cancer Institute. Esophageal Infection. NCI Thesaurus. Code C78277.

An infectious process affecting the esophagus. 